\title{
Entering into a community-university collaboration: Reflections from East New York Farms!
}

\section{FoodDignity}

\author{
Sarita D aftary-Steel * \\ Former director of East New Y ork Farms!, United Community Centers
}

Submitted April 11, 2018 / Published online July 18, 2018

Citation: D aftary-Steel, S. (2018). Entering into a community-university collaboration: Reflections from

East New York Farms! Journal of A griculture, F ood Systems, and C ommunity D evelopment, 8(Suppl. 1), 5- 7.

https:/ / doi.org/ 10.5304/ jafscd.2018.08A.013

Copyright (C 2018 by the Author. Published by the Lyson Center for Civic Agriculture and Food Systems. Open access under CC BY license.

$\mathrm{I}$ worked as the director of the East New York Farms! (ENYF) Project for seven years, from 2006 to 2013. As media interest and general excitement about sustainable food grew during that time, assessing potential opportunities for "partnership" and participation in the broader world of sustainable food work (that is, outside East New Y ork) became an increasingly important part of my role and an increasingly significant way in which we defined what we were, and were not, about.

The route to participation by ENYF in Food Dignity started with Megan G regory, a Ph.D. student at Cornell, inviting our then farm manager, David Vigil, and some of our youth leaders to speak at a conference in Ithaca, New Y ork. I remember David coming back and telling me that "they treated us like royalty," as he described being picked up in Ithaca, taken out to dinner at the world-famous Moosewood Restaurant, and

* Sarita D aftary-Steel, former director of East New Y ork Farms! (http:/ / www.eastnewyorkfarms.org), United Community Centers; East New York, Brooklyn, New York; daftarysarita@gmail.com generally welcomed and appreciated by Megan and the other hosts at Cornell. We accepted the invitation to this conference largely because of the leadership-development opportunity it afforded to our youth members to share their experiences in food justice work and hear from others. Had it been an invitation for just our staff to speak, we may not have felt that we could justify committing the time to this; invitations to food-related conferences were frequent, but we always prioritized our work on the ground.

In May 2010, Megan reached out to D avid to assess our interest in joining as a partner in the Food Dignity project (not yet so named) and made an introduction to Christine Porter, who was finishing her Ph.D . at Cornell. Looking back at that email, which David forwarded on to me, I think a few things made it an appealing invitation. First and foremost, the intention of the proposal was aligned with our goals and the work we were already doing (more on that below). That was, of course, the key component. But other, smaller elements probably helped too. At a simple level, 
the description of our participation included a budget (then described as about US\$50,000 per year for each partner). So it was clear from the beginning that this was not a situation in which we'd be asked to contribute many hours in exchange for a US\$500 honorarium or something like that. The fact that it was a five-year project was also important in making us feel that our investment of time and learning would be worthwhile. In addition, the other project partners were already identified at that point, and it seemed that our work could be strengthened by joining a long-term learning community with those peer organizations doing similar work in different locations and contexts all over the country. Lastly, the initial offer came from someone we'd worked with, had a good experience with, and had reason to trust (Megan).

In terms of the direct relevance to our work, there was a clear connection in the intention to provide microgrants- something ENYF had already been working toward for some years. In 2004, when we were a grantee of Heifer International, it helped us to develop a revolving loan fund, which we named the Backyard Exchange Fund. This fund was managed by a committee of gardeners and helped us to directly support projects that our members wanted to initiate. This model of responding to and supporting community leadership was always important to ENYF. But the fact that the Backyard Exchange Fund provided loans was challenging. Not because people took out loans and didn't pay them back - they did, in fact- but because it seemed that taking on a loan was a deterrent. Understandibly, we didn't receive many applications. None of our gardeners was pursuing a project that would be so profitable for them as to think that taking out a loan would be wise or safe, especially because selling products within our community at affordable prices has always been a focus of ENYF and our market vendors. To encourage more applications, we tried at one point providing a combination of loans matched by grants, which seemed to encourage a few more applications. We had long felt that if we could provide grants rather than loans, we would be better able to support community members to increase access to fresh food in East New York.

While I don't think we, or perhaps I, fully grasped the scope and benefits of the research component of Food Dignity at first, I believe we still saw value in getting support to capture and share our stories - with assurance that researchers would help us to answer the questions that mattered to us. We imagined these stories could help us in demonstrating the true value of our work to funders and potential funders, and in better understanding and articulating the impact of that work ourselves.

Those combined factors made it feel worth it for me to set up a conversation with Christine, made me walk away from that conversation feeling like it was a viable opportunity to discuss with the rest of our staff, and made us ultimately feel that it was a good opportunity to pursue. And the next steps- writing a letter of support, reviewing budgets and the scope of work documents- were not too onerous and were spread out over a couple of weeks. Throughout that process, it felt clear to me that Christine was making a real effort to communicate with all of us, incorporate our input, and respond to our concerns.

I think it's relevant also to note that ENYF may have had the lowest barriers to overcome in considering a partnership with an academic institution. Through the course of the Food Dignity project, I learned much more about the historical and current tensions between universities and communities, and even between individual academics and their institutions. But for me certainly, and I think for most of us at ENYF, universities and academics had just never been much of a reference point for our work - either because N ew Y ork City is such a huge city that no university seems to cast a significant shadow (and certainly not in East NY), or maybe because ENYF had on average the youngest staff among the community partners. We had neither strong positive nor negative associations. To even say that academic and research institutions felt far removed from our work might overstate the degree to which we were thinking about them. They just felt like a nonfactor.

I think that there were many reasons for ENYF, and me as the project director, to have a healthy sense of caution around developing new partnerships. After all, the world of sustainable food work is vast and only a small portion is 
Journal of Agriculture, Food Systems, and Community Development ISSN: 2152-0801 online

https:/ / www.foodsystemsjournal.org

rooted in community leadership in the same way that we strive to be; the work of small neighborhood-based organizations is often not truly valued in the design or implementation of partnership projects; and East New York and East New
Y orkers have been on the losing end of many plans and promises. I'm grateful that, in this case, we were able to run this invitation through all of our filters and find an opportunity to work in genuine partnership. 